\title{
Do the abiotic environmental factors influence the reproduction rate in the free-ranging European bison in Białowieża Primeval Forest?
}

\author{
Janusz GILL
}

Gill J. 1998. Do the abiotic environmental factors influence the reproduction rate in the free-ranging European bison in Białowieża Primeval Forest? Acta Theriologica 43: 417-432.

Abiotic factors such as sunspot activity, radiation, insolation, air temperature and rainfall in the Białowieża Primeval Forest were measured for 26 years and the number of mature cows and bulls, calves born each year, bull/cow and calf/cow ratios were counted. Results showed that, in 26 years, 984 calves were born (482 males and 502 females). The sex ratio was 0.96 . The number of calves depended mostly on the bull/cow relation which changed from 0.12 to 0.46 . Calf/cow ratio changed from 0.32 to 0.92 . The rainfall in September was the most important abiotic factor. Less rain was associated with more male calves and an alteration in the male/female ratio in next year. The same concerns the calf/cow ratio. Rainfall over $3 \mathrm{~mm}$ in September diminished this ratio to 0.6 . The other abiotic factors did not influence the fertilisation in the bison cows in the 3 autumn months. However, they showed the range of environmental indices, to which all animals living in the Forest must adapt their metabolism.

Department of Vertebrate Animal Physiology, Zoological Institute, University of Warsaw, Żwirki i Wigury 93, 02-089 Warszawa, Poland

Key words: Bison bonasus, reproduction, Białowieża Primeval Forest, environmental factors, meteorological data, number of calves

\section{Introduction}

Since the Middle Ages (13th-14th centuries) Białowieża Primeval Forest has been the main living area and feeding base for the European bison Bison bonasus (Linnaeus, 1758). It lived here in the natural environment until 1919, when the last cow was shot (Krasiński 1978). Before that, for hundreds of generations, the European bison adapted its metabolism to two factors: (a) diurnal and annual rhythms and (b) food. The action of the first factor causes many biorhythms. The second one ensures the supply of energy and materials for the structure and function of organism. All physiological phenomena are the results of the action of these two groups of factors.

The literature data state, that, until extinction in 1919, the cyclicity of reproduction, as one of the most distinct seasonal phenomena of wild ruminants, 
was observed (Wróblewski 1927). We have no information of European bison metabolism at those times, except that calving period occurred in spring, mostly in May. This suggests that estrus period took place in autumn, mostly in September.

In 1929, European bison were reintroduced into the Białowieża Primeval Forest, but they were bred only in enclosures. They were fed by man in the way which was more typical for domestic cattle rather than for wild ruminants. The food was rich in protein and minerals. The bison ate all the bushes and small branches from trees within their enclosures. Thus they were exposed to much more light then in any dense forest.

This led to the loss of the cyclicity of reproduction. The bison cows started slowly to exhibit estrus over the whole year and, as a consequence, they calved in all months of the year (Jaczewski 1958). Therefore, the abundance of food rich in many compounds and more light resulted in breaking the natural ability of metabolism to react to seasonal changes.

In 1952, the European bison were gradually reintroduced into the forest, as a free-ranging herd, to mostly natural food and to natural light conditions. Then, within a few years, the reproductive system began returning to its normal cycle. The calving period rapidly narrowed to five summer months (Krasiński and Raczyński 1967, Krasiński 1978). This has been a good example of the bison's abilities, when living in more natural environmental conditions, to free its metabolism from the influence imposed by man (Gill 1967).

At present, the number of European bison living as the free-ranging herd in Białowieża Primeval Forest is steadily increasing. To keep the population size in the limit of about 230 heads, some of them are eliminated by killing. The number of calves born every year fluctuated between 24 and 57 individuals. This is a great range, in the case of nearly the same number of mature cows and bulls. The range of mature cows in the herd changed from 44 to 120 within 26 years. The factors, which can influence the probability of fertilisation in the estrus period or the course of pregnancy, are unknown.

The factor which could induce the estrus period and fertilisation is a complex of environmental factors, such as the temperature, rainfall, sunshine, radiation and sunspot activity. We decided to study changes in these factors in the Białowieża Forest, in three months when bison cows exhibit estrus, eg August, September, and October. Comparisons were made over a 26 year period.

\section{Material and methods}

In the Białowieża National Park steady professional meteorological (meteo) measurements have been recorded. We used the data concerning the daily temperature measured $2 \mathrm{~m}$ above the ground (in ${ }^{\circ} \mathrm{C}$ ), the amount of rainfall (in $\mathrm{cm}$ ), radiation (in $J$ ) and the amount of sunshine (in hours per day). The data for three months (August, September, and October) were used every year since 1970 till 1995 .

The number of the European bison living at large in the Białowieża Primeval Forest had been recorded at the end of December, each year. During the recording procedure the number of bulls and 
cows over 4 years of age, the youth and calves below 1 year, of both sexes, were identified. The results were taken on December 31st of every year. It is necessary to add that, in the Primeval Forest, there is no possibility to record the number of bulls and cows during the breeding season. In this paper we used the number of cows over 4 years of age and number of calves, males and females, born in the appropriate year, from 1970 till 1995.

The number of bison from 1970 till 1993 were given after Krasiński et al. (1994), and for 1994 and 1995 were taken from the Białowieża National Park.

To evaluate the influence of meteo data on the reproductive status of the European bison we compared the data with the number of calves born in the next year (eg the meteo data for three months of 1970 were compared with the number of calves born in 1971).

Seven variables pertaining to the European bison population (calf sex ratio, number of calves, number of female and male calves, ratio of female (or male) calves born to mature cows, ratio of mature bulls to mature cows) were compared with 24 meteorological variables (temperature, rainfall, solar radiation and insolation in three consecutive months of autumn). To this end cluster analysis was applied. Firstly, a matrix of correlation coefficients between all the variables was computed. The next step was clustering performed by means of UPGMA method.

A minimum spanning tree was also determined. It reveals relationships between the European bison population and meteo variables. More explanation is given in discussion. All calculations were performed with the use of TYTAN 87 package (Batko and Moraczewski 1988).

It is known that the sun's activity and its cyclic appearance have many terrestrial consequences (Stoupel 1980, Stoupel and Shimshoni 1984). It has been shown that the sun's activity influenced the levels of prolactin, growth hormone and corticoids during high and low activity days (Stoupel et al. 1983), and also the weight and length at birth of human newborns (Merlob et al. 1995). Therefore, we used the solar activity measured by sunspot number (Wolf number) for 26 years. The data have been delivered to us by the Astronomic Institute of the Wrocław University, Poland.

While preparing the materials we gathered over 10 thousands of separate indices. All of them were analysed by computer program described above. Results are shown in Figures concerning correlations. To visualize the course of separate indices during 26 years, we prepared the Figs 1-6, based only on average values, without giving the range of SE or SD These last data could obscure the pictures.

\section{Results}

The activity of the Sun expressed by sunspots number (Wolf number) showed distinct cyclicity over Poland, comprising the 11 year-long cycles (Fig. 1A). The activities taken for August, September and October of each year covered the lines representing the Wolf number for whole year. For this reason they were not put in the Fig. 1A. This means that the sun's activity had no fluctuations in the 3 autumn months, independently of the state of high of low activity. The sunspot number did not influence the number of the bison calves born in the period of 26 years.

The values of insolation expressed as hours per day (Fig. 1B) changed distinctly in the 3 autumn months. An influence of sunspot number on the isolation in the Białowieża Forest can be observed, especially for August, from 1977 till 1987. The insolation in September and October was less apparent and the courses were different from 1971 till 1983 and from 1984 till 1990. After 1991 this value was not measured. This parameter did not influence the number of bison calves born in 26 years. 

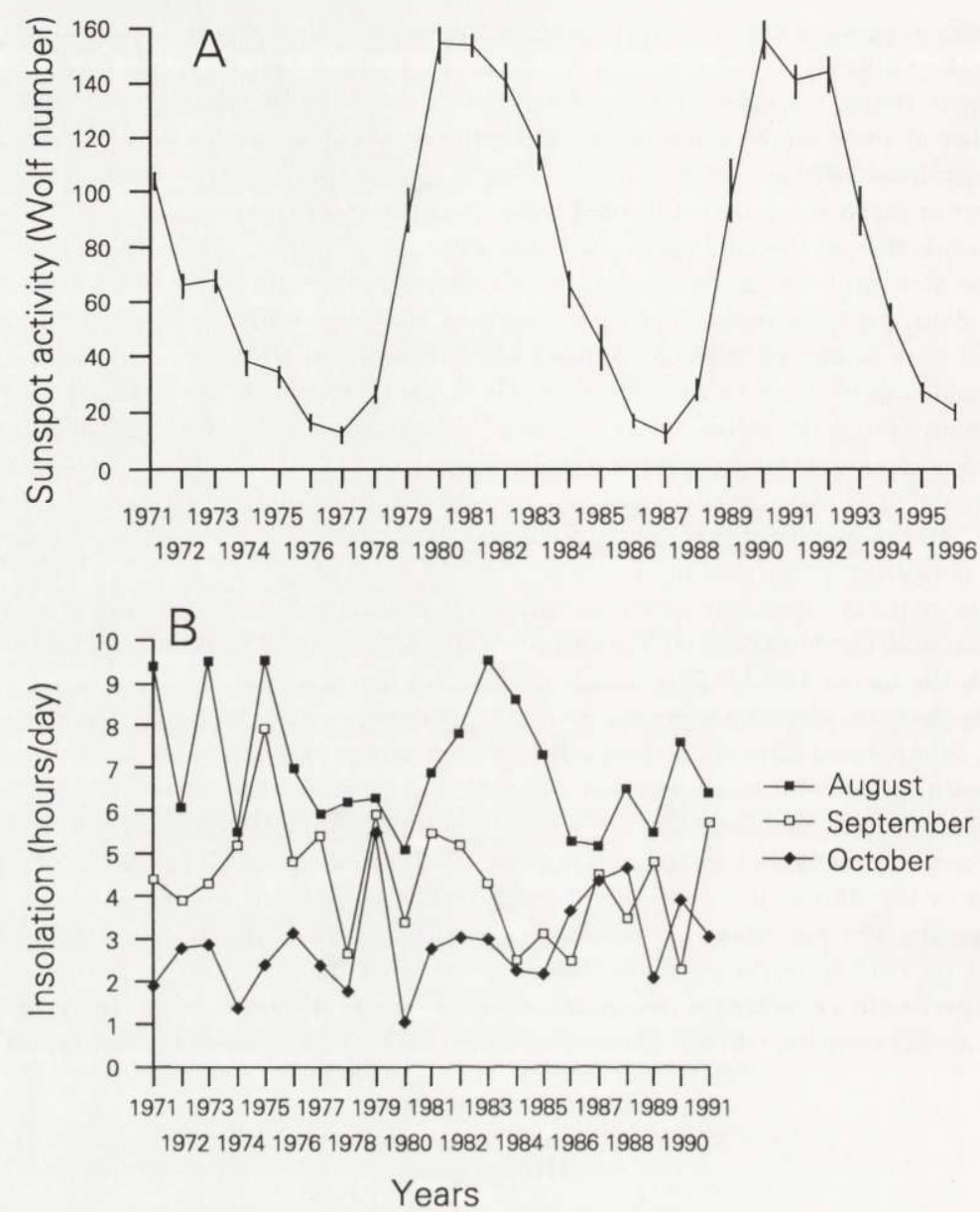

Fig. 1. A. Sunspot activity (Wolf number) over Poland, during 26 years. B. Level of insolation (hours per day) of the Białowieża Primeval Forest in August, September and October, during 26 years.

The radiation for August reflected the activity (in J) of the Sun, except the years 1973-1975 (Fig. 2). The courses of radiation in September and October were very different. In October of all years the radiation was rather low. This parameter also had no influence on the number of calves.

The mean monthly temperatures for August, September, and October were different in consecutive months (Fig. 3A). It is seen from the Figure that this parameter does not depend on sunspot activity but more on signs signalling approaching winter. The mean annual temperature of October never reached the one of September.

The Białowieża Primeval forest lies on the boundary of two climates: continental and Atlantic one. It is situated between $52^{\circ} 45^{\prime}$ North and $23^{\circ} 50^{\prime}$ East. The highest 


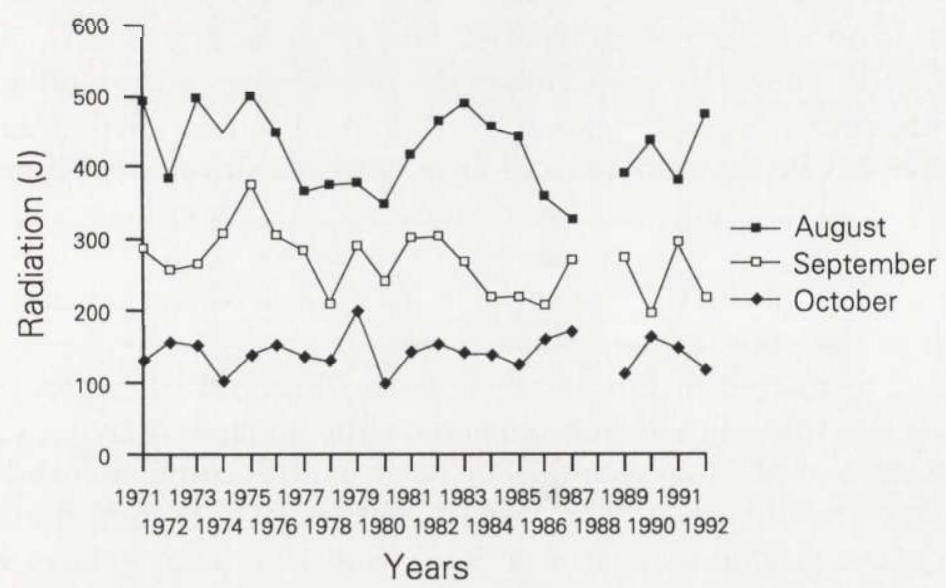

Fig. 2. Level of radiation (in J) of the Białowieża Primeval Forest in 3 autumn months, during 26 years.
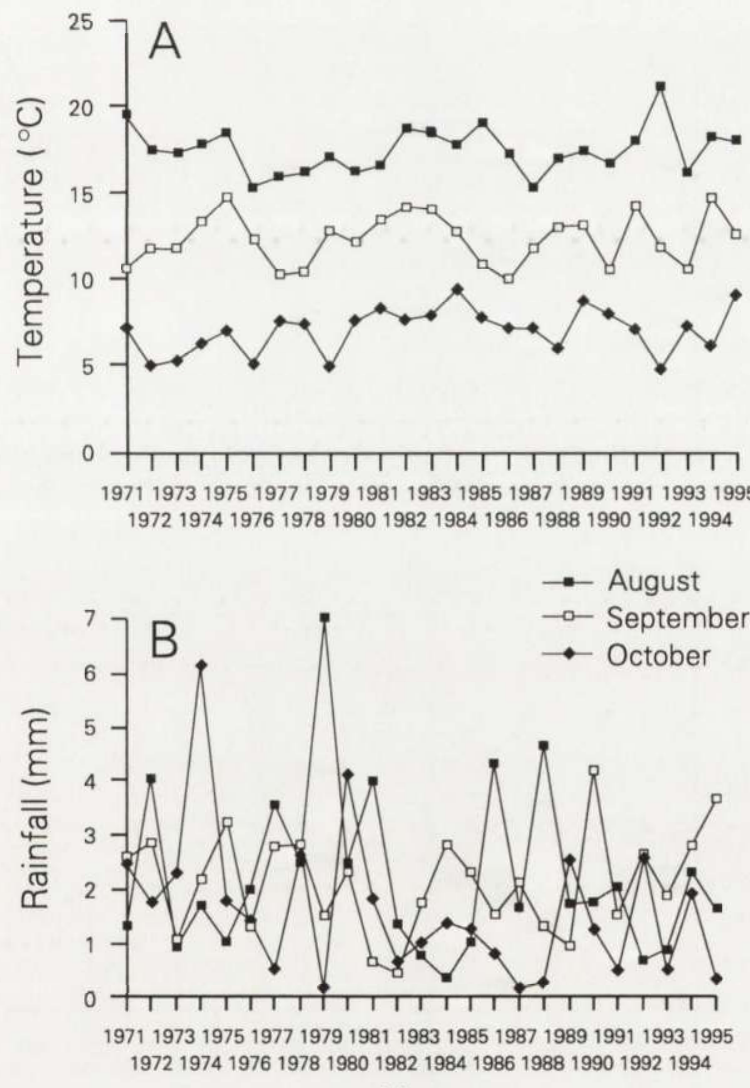

Years

Fig 3. A. Changes in air temperatures in the Białowieża Primeval Forest in autumn months, during 26 years. B. Levels of rainfall in the Białowieża Primeval Forest in 3 autumn months, during 26 years. 
mean temperature of August fluctuated mostly around $17-18^{\circ} \mathrm{C}$, only once it reached $28.7^{\circ} \mathrm{C}$ (in 1992). But in October the temperatures were often below $0^{\circ} \mathrm{C}$. It was recorded for 6 years. For example: -0.1 to $-1.6^{\circ} \mathrm{C}$ in 1976 ( 7 days), -1.6 to $-4.6^{\circ} \mathrm{C}$ in 1979 ( 7 days), -0.5 to $-2.4^{\circ} \mathrm{C}$ in 1991 ( 6 days). However, the mean temperature was higher in 1991 than in 1992 , when it went below $0^{\circ} \mathrm{C}$ in one day only.

That situation extort distinct changes in bison metabolism pressing to prepare the organism to the approaching winter.

The rainfall measured in $\mathrm{mm}$ is presented in Fig. 3B. There are two facts to be noticed: (a) the rainfall does not depend on the sunspot activity, (b) the mean monthly amounts of rain are similar in each of 3 autumn months. In several different years the amounts were small, only $1-2 \mathrm{~mm}$ per month. It is a consequence of the fact that sometimes there were 10-20 days of dry weather. On the other hand, there were days with $27 \mathrm{~mm}$ or more of rain. We presented means for a month.
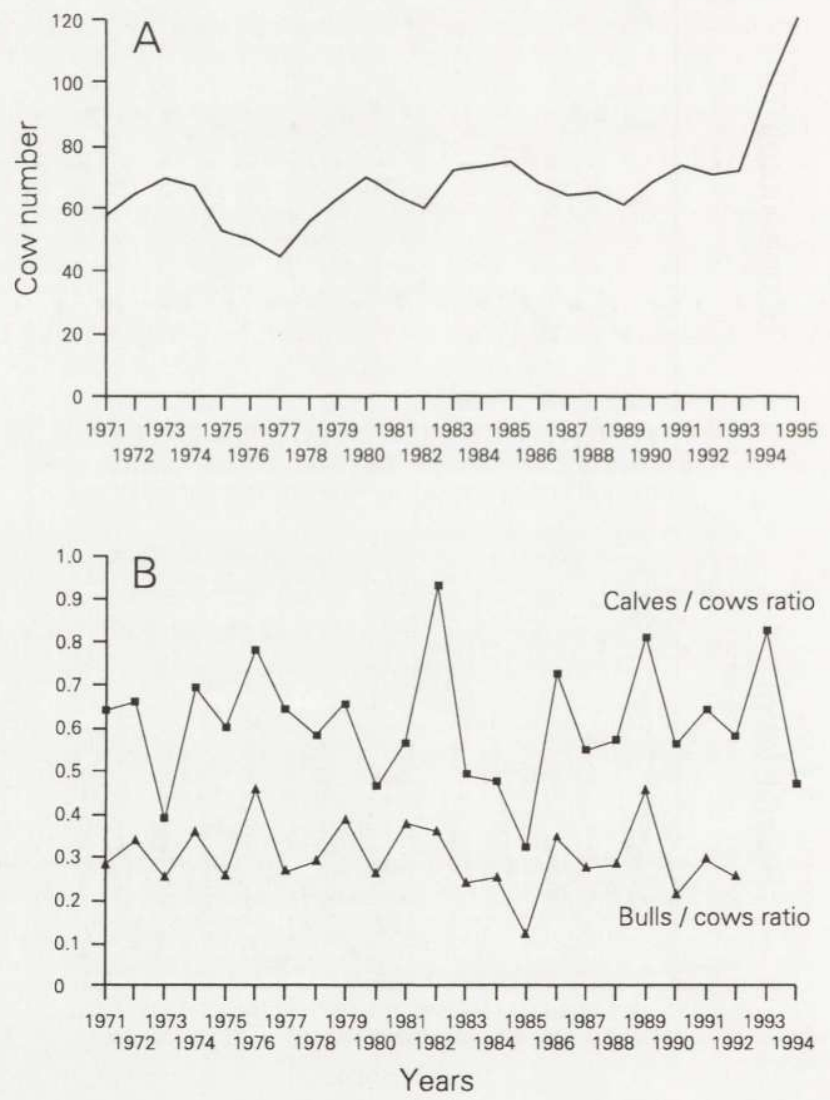

Fig. 4. A. Number of the European bison cows. B. The bison calves/cows ratio and the bison bulls/cows ratio in the free-ranging herd in the Białowieża Primeval Forest, during 26 years. 
This parameter had an influence on the European bison reproduction rate which presented in Figs 8, 9 and 10.

As it is seen from Fig. 4A, the number of mature bison cows, over 4 years of age, changed in the period of 26 years from 44 in 1977 to 120 in 1995. In the majority of years the number fluctuated around 60 . To keep the population size within well determined limits some of them were eliminated by killing. But technical conditions in the Primeval Forest not always allowed for elimination of the planned number of bison from each age and sex class. Thus some cases of natural death and maturity of haifers cause the change in number of mature cows in a separate year.

Fig. 5 shows the number of bison calves born over the 26 year period. It changed from 24 in 1986 to 57 in 1994 . The mean number was 37.9 per year.

The sex ratio of calves changed widely (Fig. 5). From 16 males : 16 females (1:1) in 1979 to $18: 9(2: 1)$ in 1974 or $9: 15(0.6: 1)$ in $1986,24: 33(0.7: 1)$ in 1994 . All together in 26 years 984 calves were born, of which there were 482 males and 502 females. The sex ratio was 0.96:1.

The relationships of calves/cows and bulls/cows are presented in Fig. 4B. It can be seen that the number of calves born by mature cows depended on the ratio of bulls to cows. This was clearly seen in 1985 , when the bull/cow ratio was the lowest - only 0.12 . The calf/cow ratio was also very low next year - only 0.32 . Similar relations were seen in 1973, 1980 and in 1990. Then, over half of cows

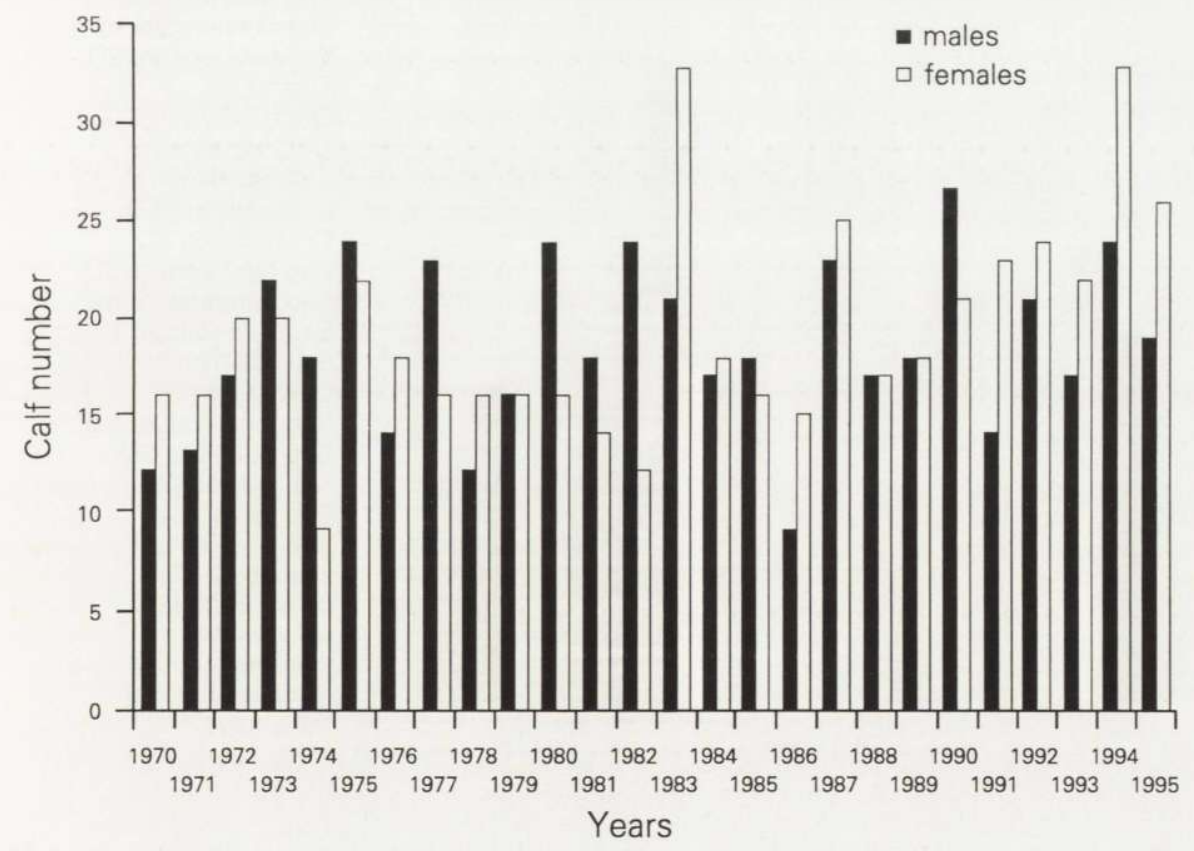

Fig. 5. Number of bison calves (males and females) born in the Białowieża Primeval Forest, during 26 years. 
were barren. When the bull/cow ratio was above 0.30 (0.34-0.46), $70-80 \%$ of cows produced calves in the following year. Of course, some other factors might have influenced the calf/cow ratio. The last ratio was the highest in 1982, it was 0.92 . This means that $92 \%$ of mature cows had offspring. In the proceeding year it was 0.56 and in the following one -0.49 . Therefore, some cows had offspring every year during 3 years.

In our study we eliminated 117 European bison cows, aged 4 to 24 years, in the course 1977 to 1997 . Among them were:

$\begin{array}{lll}\text { barren } & 59(50.4 \%), & \text { (18 cows aged } 20-24 \text { years); } \\ \text { lactating } & 29(24.8 \%), & \text { ( } 5 \text { cows aged } 20-23 \text { years); } \\ \text { pregnant } & 22(18.8 \%), & \text { (all below 20 years); } \\ \text { lactating and pregnant } & 4(3.4 \%), & (1-20,1-21 \text { years old); } \\ \text { in estrus } & 3(2.6 \%), & (1-13,2-16 \text { years old). }\end{array}$

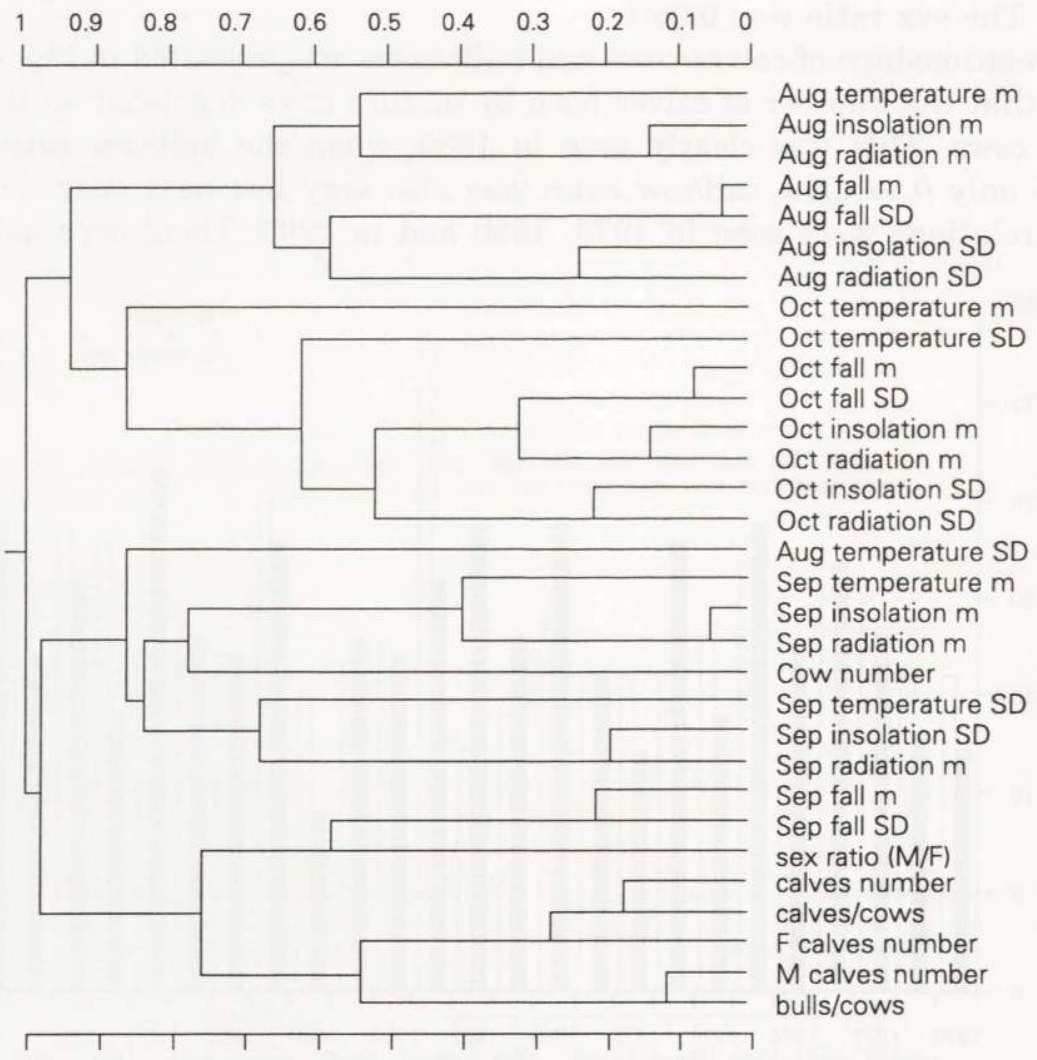

Fig. 6. Dendrogram resulting from cluster analysis of all variables analyzed. Variables pertaining to the European bison population and meteorological variables for September make a group. $\mathrm{m}$ - mean values, $\mathrm{SD}$ - standard deviation, $\mathrm{M}$ - males, $\mathrm{F}$ - females. 


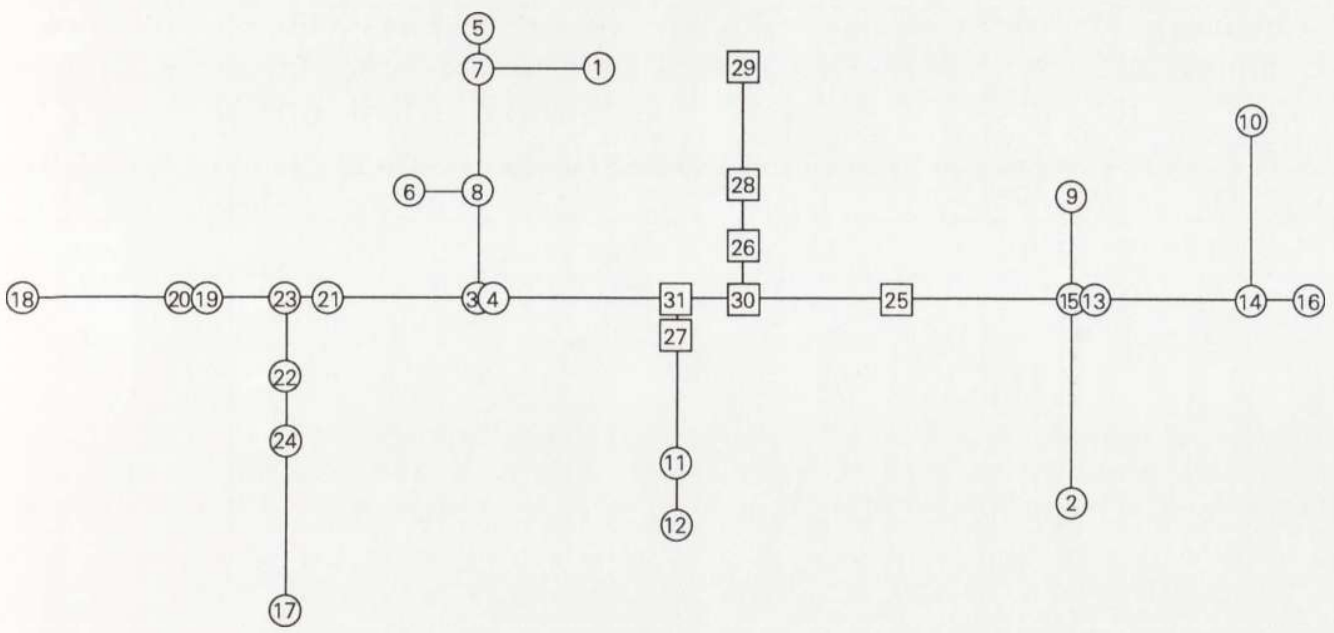

Fig. 7. Minimum spanning tree obtained for the set of all variables studied. All variables pertaining to the European bison population (squares) occupy the central part of the tree, except of cow number (node 25).

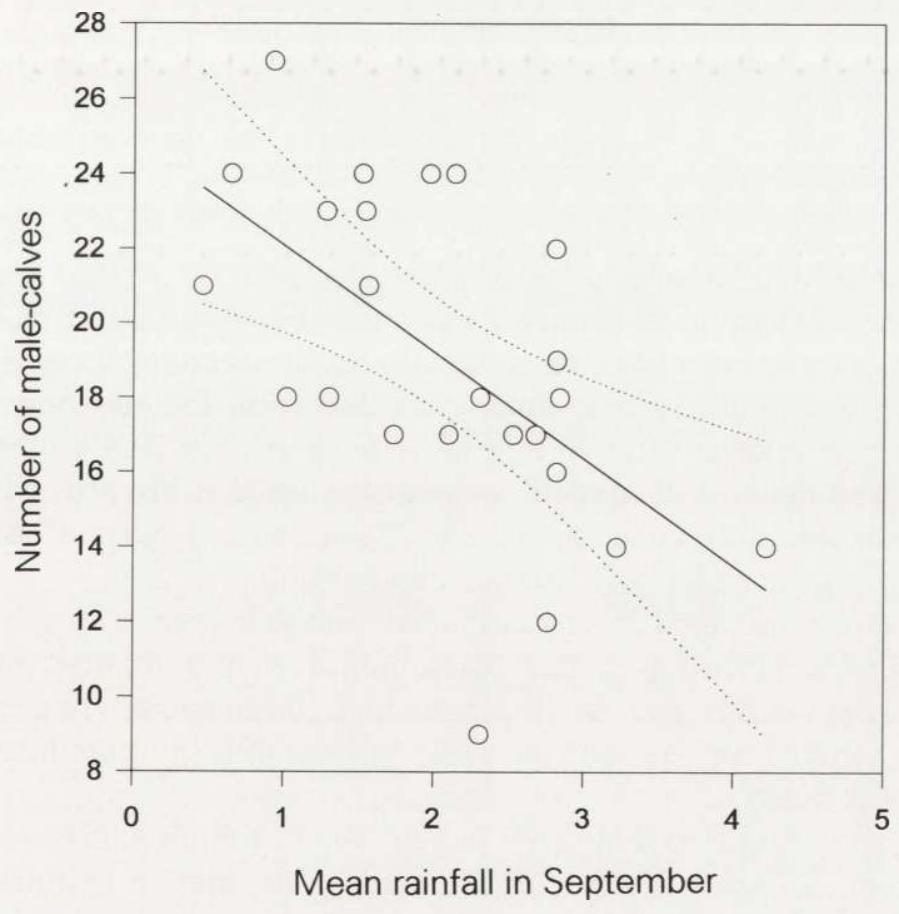

Fig. 8. Correlation between the mean rainfall in September and the number of the male bison calves, born in 26 years. 


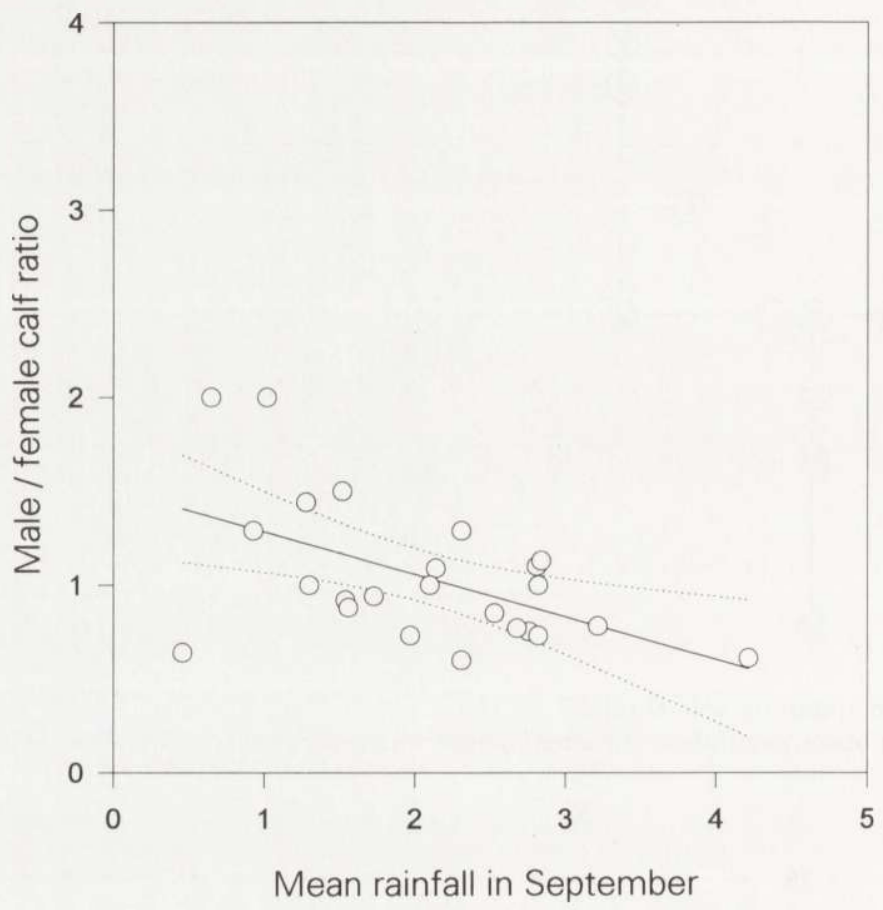

Fig. 9. Correlation between the mean rainfall in September and the ratio: male-calf number to female-calf number, in 26 years.

Therefore, it is visible that only 7 cows (out of $58=12.1 \%$ ) in the age of 20 years were in the reproductive state. Among those pregnant 4 cows were 4 years old, and 5 in the age of 5 years. Among the lactating females only one cow was in age of 4 years and one in the age of 5 . As many as $50.4 \%$ of all cows were barren. This was not in full agreement with the data of Fig. 4B, which indicates that some cows should have calves in 2 or 3 consecutive years. Conditions of our study however can not give any further explanation.

In the dendrogram resulting from cluster analysis (Fig. 6) a group consisting of all variables pertaining to the bison population and most meteorological variables for September can be distinguished. It suggests that meteorological factors in September can account for some aspects of bison population variability analysed in this study.

Minimum spanning tree displayed in Fig. 7 is to a high degree consistent with the dendrogram. All variables pertaining to bison population (squares) occupy the central part of the tree. The only exception is the cow number (node 25). Some of the meteorological variables (circles) are located far away from the middle of the tree, eg SD temperature in October (17), SD temperature in August (2), temper- 


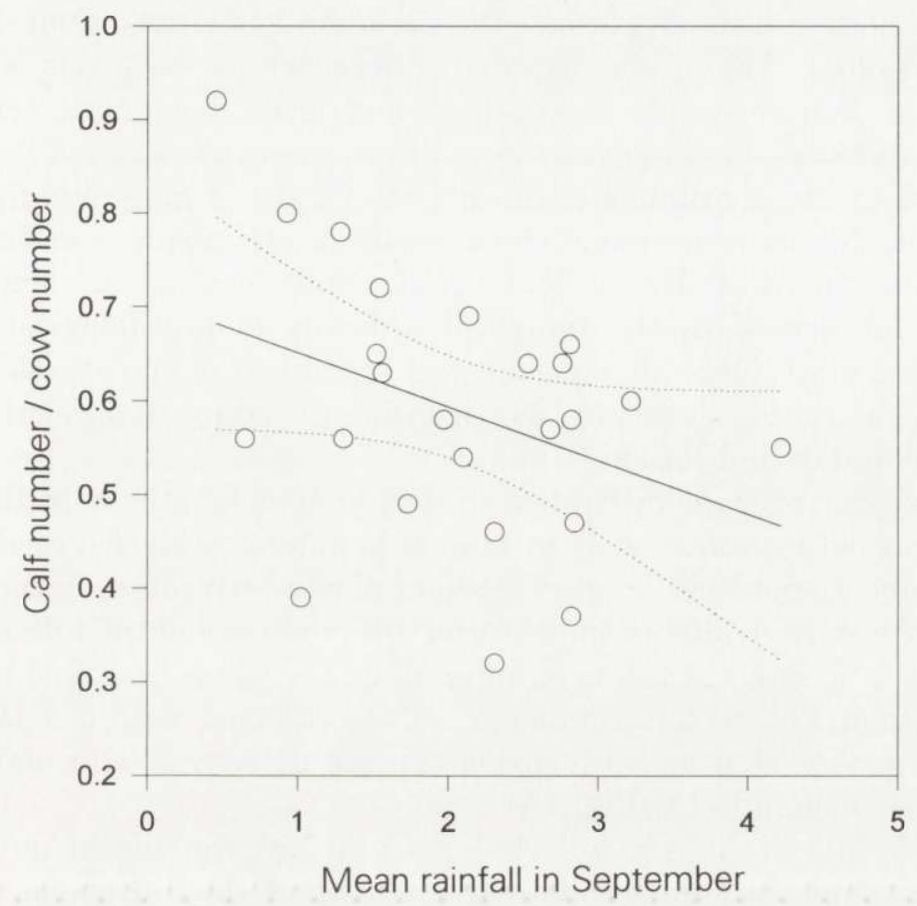

Fig. 10. Correlation between the mean rainfall in September and the ratio: number of bison calves to number of bison cows, during 26 years.

ature in September (9), SD radiation in September (16). The numbers within circles and squares mean variables given in Fig. 6, counted from top (1) down (31).

The analyses of correlations showed two groups of results. The first one, with no correlations involved: the Wolf number and amount of calves, the mean rainfall in September with the number of calves (correlation coefficient -0.39), and the number of female calves $(-0.34)$. The second group, with distinct correlations, was formed by the mean rainfall in September with the number of male calves (correlation coefficient -0.61 ; Fig. 8 ), with the ratio: male-calf number to female-calf number (-0.53; Fig. 9), and with the ratio: number of calves to number of cows was on the boundary of significancy: -0.34 (Fig. 10).

\section{Discussion}

The first point to be discussed is the steady action of the Sun on the life of all organisms on the Earth.

The sun's activity and its cyclic appearance have many terrestrial implications (Stoupel 1980, Stoupel and Shimshoni 1984). Diurnal and seasonal cyclicity in 
hormonal secretions and activity affects the circadian and circaannual rhythmicity in human physiology. The studies showed differences in the levels of prolactin, growth hormone and corticoids during high and low geomagnetic activity days (Stoupel et al. 1983).

With regard to the possibility of the direct efficacy of magnetic field and its disturbances on the neuro-hormonal regulations in organisms - an influence on pineal gland functions was shown (Semm et al. 1980). The pineal gland hormone, melatonin, is implicated in the temporal ordering of physiological variables. Melatonin affects most, if not all, physiological variables (among others TSH, FSH, $\mathrm{LH}, \mathrm{Gh}$, beta endorphin, serotonin) which influence many that regulate animal reproduction (Randall and Randall 1991).

A statistically significant difference in weight and length at birth measurements was achieved for total newborn human population (Merlob et al. 1995).

It is impossible to measure length or weight of newborn calves in the European bison. Thus, the only available measure of the environmental influence is the number of calves counted at the beginning of winter when frost and snow come. As it is seen from Fig. 5, the number of calves changed within a large range. Perhaps the reason is that an influence of sunspot activity (Wolf number) on the calf number was insignificant (Fig. 1A).

However, in this study we collected a lot of environmental data and the comparison of them with the reproductive status of the European bison gave interesting findings. First of all it is apparent that the biological life of the whole Białowieża Primeval Forest runs in changeable conditions, sometimes with a great deal of variability, see Figs $1-3$. The sunspot activity plays a distinct role in the course of radiation, insolation and temperature in the whole complex of the forest, an area of over 1300 square kilometers.

The second point to be discussed is the ability of the European bison in the past to change one of the fundamental features of wildlife such as the seasonality of reproduction. Those changes occurred within a very short period of time.

A great part of the answer to the question on those changes gives the study on levels of three sex hormones (Gill 1997). It seems that the European bison exhibits nearly a steady level of production and secretion of sex hormones. Neither sex nor physiological state of mature cows changed the mean level of hormones circulating in the blood, e.g. available for their target organs. Especially worth noting is the fact that testosterone appears in the same amount in bulls as well as in young females and mature cows. Estradiol and progesterone are in the blood of males on the same level as in the barren, pregnant or lactating cows aged over 3 years.

That feature of the European bison is surprising as compared with other large ruminants living in different climate zones and temperature relations. Extensive studies made on biology of the water buffalos in India, Indochina and the southeast Asian islands showed that many aspects of the reproduction depends on the amount of sunshine, temperature and humidity (Cockrill 1974). Although water buffalo have been domesticated for many generations seasonal variation in the 
reproductive function was more pronounced in the buffalo than in the cow (Cockrill 1974, Kamonpatana 1985). So, the cyclicity of reproduction has been preserved until now.

The reproduction of water buffalo is similar to the reproductive rate in the American bison. Lott (1991) stresses that the strong seasonality of breeding and birth in American bison appears adaptive to the climatic seasonality of the environment. The highly cyclic nature of food abundance expresses a smaller part in the cyclic reproduction of this species. Berger (1992) stated that bison cows in good condition, which were mated after the seasonal peak, shortened gestation by approximately 6 days, synchronizing births with other females. No similar adjustments occurred among cows in poor condition.

Studies on 40-60 American bison in southern Ukraine showed that oogenesis and estrus occurred only in summer and autumn, and spermatogenesis increased markedly in summer. Most matings and conceptions occurred in August and the first 10 days of September (Steklenev 1987).

As illustrated in Fig. 5 the number of calves born differed from year to year, independent of the sunspot activity or on other factors studied. It is possible to find different informations in many studies on the American bison herds. The bison cows were pregnant in $48.2 \%$ and only $15.4 \%$ pregnancies were among lactating cows, which is due to lactational anovulation (Kirkpatrick et al. 1993). Old females bore their last calves unusually late (Green and Rothstein 1993), and maternal condition had no effect on the sex ratio of their offspring, although the last calves of old females were nearly always female (Green and Rothstein 1991).

There is a hypothesis that bison cows in relatively good condition will produce a higher proportion of male offspring than cows in relatively poor condition. To support that hypothesis it was pointed that from 53 lactating bison cows observed in 3 year-long studies $48 \%$ were carrying a male foetus and from 29 non-lactating ones $86 \%$ had male foetuses $(p<0.005)$. The non-lactating cows were in better condition that lactating ones in the previous year (Rutberg 1986).

As is seen in Fig. 4B, some European bison cows produced calves in two or more subsequent years. But in the forest it is impossible to know which cows had calves in two or more years.

There was an idea that in the American bison, cows show a 3-year cycle and that a calf is produced in each of the 2 successive years, but not in the $3 \mathrm{rd}$. In the 4 or 5 year studies of Lott and Galland (1985), of 12 bison cows 4 cows had calves in the 3 successive years, 2 cows did not calve in the 2 successive years and at last 3 cows had only one calf in 3 years.

In American bison calving rates were significantly lower among 2- and over 13-years old females than among 3-13 years old ones. Mature cows produced from 3 to 7 calves (Shaw and Carter 1989).

Lott and Galland (1987) observed the variation in fecundity in different American bison populations. They report that in very favorable conditions bison 
may have a fecundity of $90 \%$. But in adverse, unfavorable conditions just hal of the mature bison cows had a calf in a given year. However, some cows calyed rarely or never.

The most interesting feature from other analyses is the influence of rainfal in September on the male-calf number. Physiological interpretation of that fact seems to an easy one. Less rain is a result of less clouds, thus more sunshine and light is coming to the animals. From many studies it is known that more light during a day results in lower production of melatonine by pineal gland. The further result is the lower action of melatonine as an antigonadal factor. Then gonads are able to produce more gonadal hormones which facilitate more distinct estrus, and matings and fertilisation.

But why does it concern only the males? It is very difficult to explain this fact. It is supposed that in a dense lowland forest a very important factor is an access of sunshine to the bison eyes. It confirms the findings from earlier paper (Gill 1993) that the European bison is an eye-minded organism. But why do the direct actions of radiation and insolation have so little influence on the reproduction rate?

It is easy to understand that significant changes in the environment may influence the hypophysial-pituitary-ovary axis, probably intensifying the secretion of greater amounts of sex hormones to produce estrus, matings and fertilisation. This way of regulation, which is normally coordinated by amount of light through pineal gland and its melatonine, liberates itself from that control when very distinct changes in the environment occur. This allows for quick changes in reproductive system.

Results of this study suggest that even small changes in some meteorological data may cause distinct shifts in occurrence of conditions for conceptions or survival of foetuses in the reproductive organs of a cow. As a result we notice smaller or greater number of bison calves in various years.

On the other hand, the information from the environment in the form of steady shortening of a day-length in late summer or early autumn activates the European bison metabolism. It is visible in the autumnal increase in hematological features, carbohydrate and other indices necessary for the synthesis of store materials (mostly fat) before winter (Gill 1989, 1990, 1991).

In the free-ranging herds living in the Białowieża Primeval Forest it is impossible to get any information of the physiological course of estrus, ovulation and corpora lutea formation. A recent study of Matsuda et al. (1996) in wooc bison from Toronto Zoo showed that estrus started at the beginning of August and lasted through September. The mean cycle length was $20.8 \pm 0.3$ days with the range of 16 to 27 days. In the females which demonstrated behavioral estrus only $50 \%$ possessed corpora lutea. This indicates that very often behavioral estrus runs without the ovulation. Thus, many environmental factors can express their influence on the processes of maturation of ovarian follicles and ovulation. As a 
consequence of this, different numbers of calves are born. However, in the European bison, a study similar to that performed in the wood bison in the Zoo, is impossible.

Summing up, we followed many abiotic factors which act on the whole life of the Białowieża Primeval Forest and related them to population dynamics of bison cows, bulls and calves over 26-year period. However, we did not obtain a complete answer to the initial question asked in this study. Nevertheless, the relationship of amount of rain in September and some features of bison reproduction indicate that weather is not without some influence on bison reproduction. The most important for the bison reproduction was the adequate ratio of mature bulls to mature cows. This is a very important indicator for people who plan and perform the management and protection of this species, which is very endangered in the contemporary environment.

Acknowledgements: The author thank to Dr Z. A. Krasiński for supplying with many data concerning the European bison and the Białowieża Primeval Forest, Dr I. Moraczewski for making statistical analyses and $\mathrm{Mr} \mathrm{T}$. Dziwiński for the technical assistance in preparing of the Figures. This study was partially supported by the National Found of the Protection of Environment and of Water Economy.

\section{References}

Batko A. and Moraczewski I. 1988. TYTAN 87. Documentation. Warszawa. (distributed by authors).

Berger J. 1992. Facilitation of reproductive synchrony by gestation adjustment in gregatious mammals: A new hypothesis. Ecology 73: 323-329.

Cockrill W. Ross. 1974. The husbandry and health of the domestic buffalo. FAO Rome: 1-993.

Gill J. 1967. The physiological properties of the European bison. Acta Theriologica 12: 349-360.

Gill J. 1989. Seasonal changes in the red blood cell system in the European bison (Bison bonasus). Comparative Biochemistry and Physiology 92A: 291-298.

Gill J. 1990. Seasonal cyclicity in carbohydrate metabolism parameters in the European bison, Bison bonasus L. Comparative Biochemistry and Physiology 96A: 435-439.

Gill J. 1991. Some indices of the European bison metabolism and their dependance on environmental factors. Proc. Intern. Symp. “Ongulés/Ungulates 91". Toulouse, France, 2-6. 09. 1991, F. Spitz, G. Janeau, G. Gonzales and S. Aulagnier, eds. Paris-Toulouse: 159-162.

Gill J. 1993. Influence of environmental factors on the deep and skin temperature in the European bison, Bison bonasus (L.). Comparative Biochemistry and Physiology 106 A: 653-661.

Gill J. 1997. Levels of testosterone, estradiol and progesterone in the serum of the European bison, Bison bonasus (L.). Comparative Biochemistry and Physiology (in press).

Green W. C. H. and Rothstein A. 1991a. Sex bias or equal opportunity ? Patterns of maternal investment in bison. Behavioral Ecology Sociobiology 29: 373-384.

Green W. C. H. and Rothstein A. 1991b. Trade-offs between growth and reproduction in female bison. Oecologia 86: 521-527.

Green W. C. H. and Rothstein A. 1993. Persistent influences of birth date on dominance, growth and reproductive success in bison. Journal of Zoology 230: 177-186.

Jaczewski Z. 1958. Reproduction in the European bison, Bison bonasus L. in reserves. Acta Theriologica 1: 333-376.

Komonpatana M. 1985. Regulation of the female endocrine status to increase reproductive efficiency in the swamp buffalo. Proceedings of Buffalo Seminar, 29.04-2.05. 1985. Bangkok: 259-278. 
Kirkpatrick J. F., Gudermuth D. F., Flagan R. L., McCarthy J. C. and Lasley B. L. 1993. Remote monitoring of ovulation and pregnancy of yellowstone bison. The Journal of Wildlife Management 57: 407-413.

Krasiński Z. A. 1978. Dynamics and structure of the European bison population in the Białowieża Primeval Forest. Acta Theriologica 23: 3-48.

Krasiński Z. A., Bunevich A. N. and Krasińska M. 1994. Characteristics of the European bison populations in the Polish and Belarussian parts of the Białowieża Forest. Parki Narodowe i Rezerwaty Przyrody 13: 25-67. [In Polish with English summary]

Krasiński Z. A. and Raczyński J. 1967. The reproduction biology of the European bison living in reserves and freedom. Acta Theriologica 12: 407-444.

Lott D. F. 1991. American bison socioecology. Applied of Animal Behaviour Science 29: 135-145.

Lott D. F. and Galland J. C. 1985. Individual variation in fecundity in an American bison population. Mammalia 49: 300-302.

Lott D. F. and Galland J. C. 1987. Body mass as a factor influencing dominance status in American bison cows. Journal of Mammalogy 68: 683-685.

Matsuda D. M., Bellem A. C., Gartley C. J., Madison V., King W. A., Liptrap R. M. and Goodrowe K. L. 1996. Endocrine and behavioral events of estrus cyclicity and synchronization in wood bison (Bison bison athabascae). Theriogenology 45: 1429-1441.

Merlob P., Reisner S. H., Shimshoni M. and Stoupel E. 1995. Fetal growth in periods of extreme solar activity. Cycles 45: 140-142.

Randall W. and Randall S. 1991. The solar wind and hallucinations - a possible relation due to magnetic disturbances. Bioelectromagnetics 12: 67-70.

Rutberg A. T. 1986. Lactation and fetal sex ratios in American bison. The American Naturalist 127 : 89-94.

Semm P., Schneider T. and Vollrath L. 1980. Effects of a earthstrength magnetic field on electrical activity of pineal cells. Nature (London) 228: 607-608.

Shaw J. H. and Carter T. S. 1989. Calving patterns among American bison. The Journal of Wildlife Management 53: 896-898.

Steklenev E. P. 1987. Reproductive activity of North American bison (Bison bison L.) in the southern Ukraine, and prospects for the utilisation of the species. Sel'skohozyaistvennaya Biologiya 6: 104-110. [In Russian with English summary]

Stoupel E. 1980. Solar-terrestrial prediction aspects for preventive medicine. Proceedings, International Solar-Terrestrial Prediction Workshop, NOAA, Boulder, Colorado.

Stoupel E., Keret R., Assa S., Kaufman H., Shimshoni M. and Laron Z. 1983. Neuroendocrinology Letters 5: 365

Stoupel E. and Shimshoni M. 1984. Solar-terrestrial predictions. Proceedings of a workshop. Mendon: 1-000.

Wróblewski K. 1927. Żubr Puszczy Białowieskiej. Wydawnictwo Polskie, Poznań: 1-232 + I-XV.

Received 4 August 1997, accepted 20 October 1998. 